\title{
Innovation in Healthcare, Innovation in Law: Does the Law Support Interprofessional Collaboration in Canadian Health Systems?
}

Nola M. Ries

University of Newcastle, Australia, nola.ries@newcastle.edu.au

Follow this and additional works at: http:// digitalcommons.osgoode.yorku.ca/ohlj

Part of the Health Law and Policy Commons

Article

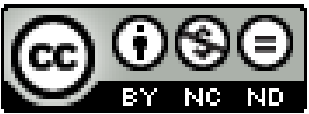

This work is licensed under a Creative Commons Attribution-Noncommercial-No Derivative Works 4.0 License.

\section{Citation Information}

Ries, Nola M. " Innovation in Healthcare, Innovation in Law: Does the Law Support Interprofessional Collaboration in Canadian Health Systems?" Osgoode Hall Law Journal 54.1 (2016) : 97-124.

This Article is brought to you for free and open access by the Journals at Osgoode Digital Commons. It has been accepted for inclusion in Osgoode Hall Law Journal by an authorized editor of Osgoode Digital Commons. 


\title{
Innovation in Healthcare, Innovation in Law: Does the Law Support Interprofessional Collaboration in Canadian Health Systems?
}

\begin{abstract}
Interprofessional collaboration in health care describes a model of practice in which multiple health professionals work together in a team-based approach to patient care. A growing body of literature demonstrates that interprofessional collaboration advances health care quality and safety, improves patient outcomes and experiences of care, and promotes job satisfaction among health professionals. Governments and health organizations across Canada are working to advance interprofessional health care delivery. This article examines the importance of law in supporting a shift to interprofessional collaboration in Canadian health care and discusses two key aspects of the legal context in which health practitioners work. First, the article discusses trends in the legal regulation of health professions in Canada, including law reform initiatives aimed at promoting collaborative practice and at expanding scopes of practice to break down the historically siloed approach to health care delivery. Second, the article examines civil liability rules that courts apply when allegations of negligence are made against health care providers working in team-based situations. regarding responsibility for patient care and outcomes. The article illustrates how legal innovations, such as new models of health profession regulation and legal adaptability through judicial understanding of the modern context of health service delivery, are important to the advancement of interprofessional collaboration in Canadian health care.
\end{abstract}

\section{Keywords}

Interprofessional relations; Medical care--Law and legislation; Medical personnel--Malpractice; Canada

\section{Cover Page Footnote}

The author is Senior Lecturer and Deputy Dean (Research), Newcastle Law School, University of Newcastle, Australia, and External Research Fellow, Health Law Institute, Faculty of Law, University of Alberta. The author acknowledges the support of the Health Services Research and Innovation Group, led by Dr Rebecca Mitchell and Dr Brendan Boyle at the University of Newcastle, Australia. The author also acknowledges Professor Ivy Bourgeault, Professor in the Telfer School of Management and Institute of Population Health at the University of Ottawa and the Canadian Institutes of Health Research Chair in Gender, Work and Health Human Resources. The author is grateful for the helpful suggestions from three anonymous peer reviewers. 


\title{
Innovation in Health Care, Innovation in Law: Does the Law Support Interprofessional Collaboration in Canadian Health Systems?
}

\author{
NOLA M. RIES*
}

Interprofessional collaboration in health care describes a model of practice in which multiple health professionals work together in a team-based approach to patient care. A growing body of literature demonstrates that interprofessional collaboration advances health care quality and safety, improves patient outcomes and experiences of care, and promotes job satisfaction among health professionals. Governments and health organizations across Canada are working to advance interprofessional health care delivery. This article examines the importance of law in supporting a shift to interprofessional collaboration in Canadian health care and discusses two key aspects of the legal context in which health practitioners work. First, the article discusses trends in the legal regulation of health professions in Canada, including law reform initiatives aimed at promoting collaborative practice and at expanding scopes of practice to break down the historically siloed approach to health care delivery. Second, the article examines civil liability rules that courts apply when allegations of negligence are made against health care providers working in team-based situations. New legislative models that provide for expanded and overlapping scopes of practice, and that introduce new professional roles into the health workforce, may raise legal concerns

* The author is Associate Professor and Deputy Dean (Research), Newcastle Law School, University of Newcastle, Australia, and External Research Fellow, Health Law Institute, Faculty of Law, University of Alberta. The author acknowledges the support of the Health Services Research and Innovation Group, led by Dr Rebecca Mitchell and Dr Brendan Boyle at the University of Newcastle, Australia. The author also acknowledges Professor Ivy Bourgeault, Professor in the Telfer School of Management and Institute of Population Health at the University of Ottawa and the Canadian Institutes of Health Research Chair in Gender, Work and Health Human Resources. The author is grateful for the helpful suggestions from three anonymous peer reviewers. 
regarding responsibility for patient care and outcomes. The article illustrates how legal innovations, such as new models of health profession regulation and legal adaptability through judicial understanding of the modern context of health service delivery, are important to the advancement of interprofessional collaboration in Canadian health care.

L'approche interprofessionnelle en soins de santé décrit un modèle de pratique dans lequel divers professionnels de la santé travaillent en équipe pour soigner les patients. De plus en plus d'auteurs s'entendent pour affirmer que l'approche interprofessionnelle fait progresser la qualité et la sécurité des soins de santé, améliore les chances de guérison des patients et leur perception des soins, tout en améliorant la satisfaction au travail des professionnels de la santé. Partout au Canada, les gouvernements et les organismes de santé s'efforcent de promouvoir la prestation interprofessionnelle des soins de santé. Cet article examine l'importance du volet juridique pour favoriser la transition vers une approche interprofessionnelle des soins de santé au Canada et discute de deux aspects essentiels du contexte juridique dans lequel œuvrent les professionnels de la santé. L'article discute d'abord des tendances de la réglementation touchant les professionnels de la santé au Canada, y compris les réformes juridiques destinées à promouvoir l'approche collaborative et à diversifier la portée des pratiques pour en finir avec l'approche historiquement cloisonnée de la prestation des soins de santé. L'article examine ensuite les règles de responsabilité civile qu'appliquent les tribunaux lorsque des accusations de négligence sont portées contre des professionnels de la santé lorsqu'ils travaillent en équipe. De nouveaux modèles législatifs qui couvrent la portée étendue et le chevauchement des pratiques et qui définissent de nouveaux rôles professionnels au sein des travailleurs de la santé pourraient soulever des questions juridiques en ce qui a trait à la responsabilité des soins et de leur résultat. L'article illustre la manière dont certaines innovations juridiques, telles de nouveaux modèles de réglementation des professionnels de la santé et la malléabilité de la loi par le biais de la compréhension par les tribunaux du contexte moderne de la prestation des soins de santé, importent au progrès de l'approche interprofessionnelle des soins de santé au Canada.

I. STATUTORY REGULATION OF HEALTH CARE PROFESSIONALS: FLATTENING THE PYRAMID

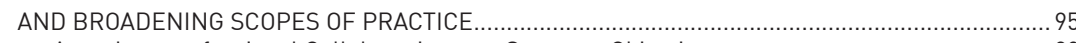

A. Interprofessional Collaboration as a Statutory Objective .................................................99

B. Expanded Scopes of Practice and New Professional Groups ......................................... 101

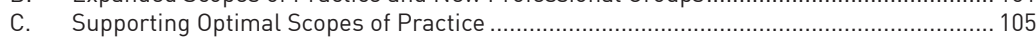

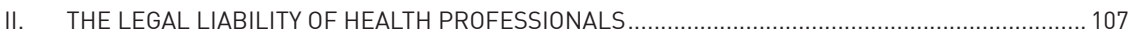

A. The Team-Based Nature of Health Care Delivery ............................................................. 108

B. Standard of Care and Responsibility for Negligent Acts ................................................ 111

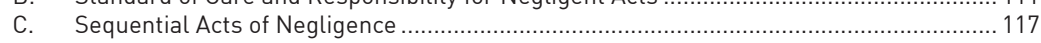

D. Health Care Organizations Must Provide Supportive Policies and Structures ................. 119

E. Legal Liability and Interprofessional Collaboration .................................................... 120

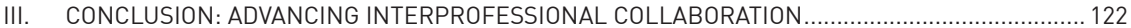

HEALTH CARE REFORM IS A CONSTANT SUBJECT OF DEBATE and policy activity in Canada. Annual government expenditures on health care have reached nearly two hundred and twenty billion dollars and the costs of operating hospitals and other facilities and paying for the health workforce account for over 60 per cent 
of this spending. ${ }^{1}$ To meet the dual objectives of controlling costs and improving patient care, governments are seeking new models of health service delivery, focusing particularly on interprofessional, collaborative team models where "the right workers with the right skills [are] in the right place, doing the right things." A growing body of literature demonstrates that interprofessional collaboration delivers higher quality and safer care, improves patient outcomes and health care experiences, and promotes job satisfaction among health professionals. ${ }^{3}$

In 2002, the landmark Romanow Commission on the future of Canadian health care advocated for fundamental reforms to promote interprofessional collaboration: "We must transform our health care 'system' from one in which a multitude of participants, working in silos, focus primarily on managing illness, to one in which they work collaboratively to deliver a seamless, integrated array of services to Canadians ..." Since then, governments and health organizations at various levels have been working-albeit slowly and incrementally-to advance interprofessional care and collaboration. In a 2003-04 First Ministers' Health Accord, federal, provincial, and territorial leaders agreed to a ten-year plan for health care reform that included a goal that, by 2011, half of Canadians would have routine access to interprofessional primary health teams. ${ }^{5}$

1. Canadian Institute for Health Information, National Health Expenditure Trends, 1975 to 2015 (Ottawa: Canadian Institute for Health Information, 2015) at 4.

2. World Health Organization, The World Health Report 2006: Working Together for Health (Geneva: World Health Organization, 2006) at xx, online: <www.who.int/whr/2006/ whr06_en.pdf?ua $=1>$ [emphasis in original].

3. For a literature summary, see e.g. Frances Legault et al, "Difficulties Encountered in Collaborative Care: Logistics Trumps Desire" (2012) 25:2 J Am Board of Family Medicine 168.

4. Commission on the Future of Health Care in Canada, Building on Values: The Future of Health Care in Canada, by Roy J Romanow, Catalogue No CP32-85/2002E-IN (Saskatoon, Sask: Commission on the Future of Health Care in Canada, 2002), online: Government of Canada <publications.gc.ca/collections/Collection/CP32-85-2002E.pdf > at xviii.

5. Health Canada, First Minister's Meeting on the Future of Health Care 2004, A 10-year Plan to Strengthen Health Care, (16 September 2004), online: <www.hc-sc.gc.ca/hcs-sss/ delivery-prestation/fptcollab/2004-fmm-rpm/nr-cp_9_16_2-eng.php>. 
While this ambitious goal remains far from realization, ${ }^{6}$ the Council of the Federation established a Health Care Innovation Working Group in 2012 with team-based models of health care delivery as one of its three priority areas. ${ }^{7}$

While interprofessional collaboration is a stated health care priority and initiatives are underway throughout Canada, a 2012 Senate inquiry reported that "adoption of multidisciplinary health-care teams across Canada" is occurring "in the form of pilot projects rather than systemic change" and is undermined by "ongoing systemic barriers" ${ }^{8}$ including outmoded regulatory and remuneration models. In 2011, the Canadian Academy of Health Sciences convened an expert panel to examine collaborative care models and optimal scopes of practice for health professionals. The final report, released in 2014, emphasized that a central problem with current models of health service delivery is that "health professional scopes of practice and associated models of care tend to be organized on the basis of tradition and politics rather than in relation to the evidence of how best to meet contemporary population health needs." The report urged numerous reforms, including changes to legal and regulatory frameworks, "to shift the health care system from one that is characteristically siloed to one that is collaborative and patient-focused." 10

6. Senate of Canada, Standing Senate Committee on Social Affairs, Science and Technology, Time for Transformative Change: A Review of the 2004 Health Accord (March 2012) (Chair: Honourable Kelvin K. Ogilvie, Deputy Chair: Honourable Art Eggleton, PC), online: <www.parl.gc.ca/content/sen/committee/411/soci/rep/rep07mar12-e.pdf> at 34:

"The committee heard from witnesses that insufficient progress had been made towards the goal of ensuring that 50 per cent of Canadians have 24/7 access to multidisciplinary teams by 2011. Though exact figures regarding the number of Canadians enrolled as patients in multi-disciplinary health-care teams is unknown, witnesses reported that 32 per cent of Canadians had access to more than one type of health-care provider."

7. For more information, see Council of the Federation, Health Care Innovation Working Group, From Innovation to Action: The First Report of the Health Care Innovation Working Group (July 26, 2012), online: <www.pmprovincesterritoires.ca/phocadownload/ publications/health_innovation_report-e-web.pdf>.

8. Senate of Canada, supra note 6 at 35.

9. Canadian Academy of Health Sciences, Expert Panel, Optimizing Scopes of Practice: New Models of Care for a New Health Care System (Ottawa: CAHS, 2014) at 19, online: $<$ www.cahs-acss.ca/wp-content/uploads/2014/08/Optimizing-Scopes-of-Practice_ REPORT-English.pdf>.

10. Ibid at 11 . 
All provinces and territories aim to implement interprofessional health teams to deliver primary health care services. ${ }^{11}$ The advancement of interprofessional collaborative care is said to be a "cornerstone" of Ontario's health workforce strategy. ${ }^{12}$ In Nova Scotia, a collaborative Model of Care Initiative has been piloted at health sites across the province. ${ }^{13}$ In 2015 , the federally appointed Advisory Panel on Healthcare Innovation released a major report advocating integrated collaborative care teams, recommending greater role flexibility for health professionals, and lamenting the persistence of the siloed "stovepipe approach that bedevils the [health] system as a whole."14

11. See Monica Aggarwal \& Brian Hutchison, Toward a Primary Care Strategy for Canada (Ottawa: Canadian Foundation for Healthcare Improvement, December 2012), online: $<$ www.cfhi-fcass.ca/Libraries/Reports/Primary-Care-Strategy-EN.sflb.ashx>; Brian Hutchinson et al, "Primary Health Care in Canada: Systems in Motion" (2011) 89:2 Milbank Q 256. Such initiatives are a promising start, but analysts contend much work is necessary to achieve the goal of well-integrated primary care services. See e.g. Grant M Russell et al, "Integrated primary care organizations: The next step for primary care reform" (2010) 56:3 Can Fam Physician 216.

12. Ontario, HealthForceOntario, Implementing Interprofessional Care in Ontario: Final Report of the Interprofessional Care Strategic Implementation Committee (May 2010) at 3, online: $<$ tools.hhr-rhs.ca/index.php?option=com_mtree\&task=att_download\&link_id=5208\&cf_ $\mathrm{id}=68 \&$ lang $=\mathrm{en}>$. In 2007, a government-funded Interprofessional Care Committee recommended a legislative review to identify enabling and hindering characteristics of provincial laws and the Minister of Health sought advice from the province's Health Professions Regulatory Agency Council on "mechanisms to facilitate and support interprofessional collaboration between health Colleges [including] ... standards of practice and professional practice guidelines where regulated health professions share the same or similar controlled acts..." See Ontario, HealthForceOntario, Interprofessional Care: A Blueprint for Action in Ontario (July 2007), online: <www.ontariostrokenetwork.ca/ stroke-rehabilitation-resource-centre/wp-content/uploads/sites/2/2013/08/01-ipc-blueprintjuly-2007-en.pdf >.

13. Nova Scotia, Department of Health and Wellness, Model of Care Initiative in Nova Scotia, online: <http://novascotia.ca/dhw/mocins/>. See also Nova Scotia, Collaborating Centre on Health Workforce Planning \& Research, Model of Care Initiative in Nova Scotia (MOCINS): Final Evaluation Report, by Gail Tomblin Murphy et al (21 October 2010), online: Government of Nova Scotia <http://novascotia.ca/dhw/mocins/docs/ MOCINS-evaluation-report.pdf>.

14. Health Canada, Unleashing Innovation: Excellent Healthcare for Canada, Report of the Advisory Panel on Healthcare Innovation (Ottawa: Health Canada, 2015) at 14, online: <www.healthycanadians.gc.ca/publications/health-system-systeme-sante/report-healthcareinnovation-rapport-soins/alt/report-healthcare-innovation-rapport-soins-eng.pdf $>$. The Report also comments: "That services that are solely publicly funded are still arranged in stovepipes has been harder for the Panel to comprehend" (ibid at 58). 
Researchers across multiple fields are investigating the conditions needed "to ensure that desirable health systems innovations take root and thrive." 15 This multidisciplinary attention is crucial as various factors at micro, meso, and macro levels influence whether and how professionals from different disciplines work together in collaborative approaches to patient care. ${ }^{16}$ At the micro level of interactional relationships between individual health care professionals, factors such as trust and effective communication are key. The meso level encompasses conditions within organizations, such as management structures and resources that support communication and coordination in teams. Macro or system-level factors exist beyond the level of organizations and include legal frameworks, health system funding structures, and compensation models for health professionals. To date, the literature on interprofessional collaboration has focused predominantly on micro-level factors. Gaps persist in understanding the effects of macro-level factors, particularly the legal-regulatory context. ${ }^{17}$

There has been no comprehensive analysis to date of the legal landscape in Canada that articulates the current state and evolution of the law and explores the legal conditions that may be necessary to help reorient health systems around integrated team approaches. This article provides this analysis and contributes to the literature at the intersection of health law, policy, and practice by examining key legislative and jurisprudential aspects of Canadian law relevant to health

15. Nancy Edwards, Margo Rowan \& Doris Grinspun, "Understanding Whole Systems Change in Health Care: The Case of Nurse Practitioners in Canada” (2011) 12:1 Pol'y, Pol \& Nursing Prac 4 at 4.

16. Gillian Mulvale, Mark Embrett \& Shaghayegh Donya Razavi, “'Gearing Up” to improve interprofessional collaboration in primary care: a systematic review and conceptual framework" (2016) 17:83 BMC Fam Prac 1, online: BioMed Central <bmcfampract. biomedcentral.com/articles/10.1186/s12875-016-0492-1>; Leticia San Martín-Rodríguez et al, "The determinants of successful collaboration: A review of theoretical and empirical studies" (2005) Supp 1 J Interprofessional Care 132; I Supper et al, "Interprofessional collaboration in primary health care: a review of facilitators and barriers perceived by involved actors" (2014) 37:4 J Pub Health 716; Sonya Morgan, Susan Pullon \& Eileen McKinlay, "Observation of interprofessional collaborative practice in primary care teams: An integrative literature review” (2015) 52 Intl J Nursing Stud 1217; Susan McInnes et al, "An integrative review of facilitators and barriers influencing collaboration and teamwork between general practitioners and nurses working in general practice" (2015) J Advanced Nursing Prac 1973.

17. San Martín-Rodríguez et al, ibid at 133; see also Ivy Bourgeault et al, "Challenging Health System Leaders to Align Optimal Scopes of Practice and Innovative Care Models to Enable Health System Transformation in Canada" (Panel presentation delivered at the Annual Canadian Association of Health Services and Policy Research Conference, Toronto, 15 May 2014), online: Canadian Association of Health Services and Policy Research <www.cahspr.ca/ en/presentation/5384b42f37dee8a72fd5018e>. 
professions and the delivery of care in collaborative, team-based models. These doctrinal sources are integrated with scholarly literature to assess the role of law as a macro-level influence in health care.

The legal context in which health professionals work is an important macro-level factor that can promote or hinder interprofessional collaboration and new models of care delivery. Regulatory frameworks, and the behaviours and norms they influence, are "one of the determinants of the shift to a culture of interprofessional regulation." 18 This legal context includes legislative instruments that regulate health professional groups-especially provisions relevant to scopes and standards of practice - as well as civil liability rules that courts apply when allegations of negligence are made against health care providers working in team-based situations. ${ }^{19}$ Health care providers' knowledge and perceptions about the legal context are another significant influence. Barriers to interprofessional collaboration include health professionals' liability fears, their confusion about what they can lawfully do within their scope of practice, and "structural boundaries" 20 between professional fields.

There is constant talk of the need for-and the challenges of-innovation in health systems. ${ }^{21}$ The thesis of this article is that innovation and adaptation are happening in Canadian law to support health system changes. Through statutory reforms, governments are seeking to flatten the pyramid on which health professions have historically been organized. ${ }^{22}$ These are removing outmoded restrictions on scopes of practice and are recognizing a broader range of health occupational groups as professions. In judicial decision making, courts are demonstrating an understanding of the modern, team-based model of health service delivery and are interpreting and adapting liability rules to support, rather than undermine, the effective functioning of such teams. Courts are reinforcing

18. William Lahey \& Robert Currie, "Regulatory and medico-legal barriers to interprofessional practice” (2005) 19:Sup 1 J Interprofessional Care 197 at 198.

19. William Lahey, Lorraine Lafferty \& Robert Currie, "Interprofessional Health Care Policy and Regulation", in Sue Coffey and Charles Anyinam, eds, Interprofessional Health Care Practice (Toronto: Pearson Education Canada, 2014), 182-207.

20. Lewis A Lipsitz, "Understanding Health Care as a Complex System: The Foundation for Unintended Consequences" (2012) 308:3 J Am Medical Association 243 at 244.

21. The most recent example is the Report of the Advisory Panel on Healthcare Innovation. Health Canada, supra note 14.

22. Chadi describes law reforms that enable broader scopes of practice for non-medical professionals as "catalytic innovations" that can promote fundamental "social change" in health service delivery. Nicholas Chadi, "Breaking the Scope-of-Practice Taboo: Where Multidisciplinary Rhymes with Cost-Efficiency” (2011) 13:2 McGill J Medicine 44 at 45. 
the view that negligence law does not presume the existence of a pyramidal model in which legal responsibility automatically flows up to a physician at the top.

Part I of this article identifies the two main models of health profession regulation in Canada and discusses law reform initiatives aimed at promoting interprofessional collaboration and expanding scopes of practice to break down a hierarchical and siloed approach to health care delivery. In all provinces and territories, various health professions are being legally empowered to perform acts that have traditionally been reserved for medical doctors, such as the authority to diagnose conditions and prescribe drugs. Part I discusses illustrative examples of law reform initiatives in Canadian provinces and territories.

Part II then examines case law related to negligence claims arising in the context of team-based health service delivery. New legislative models that provide for expanded and overlapping scopes of practice and introduce new professional roles into the health workforce may raise legal concerns regarding responsibility for patient care and outcomes. Liability risks are a perennial concern for health professionals and "the increasing trend toward new models of collaborative, interdisciplinary practice ... has given rise to an associated uncertainty regarding liability issues in such models." ${ }^{23}$ A recent research synthesis of barriers and facilitators to collaborative practice found that legal liability concerns are a commonly reported obstacle, especially for physicians who believe they may incur responsibility for the actions of other health care providers with whom they collaborate. ${ }^{24}$ It is therefore important to examine legal liability principles

23. Conference Board of Canada, Liability Risks in Interdisciplinary Care: Thinking Outside the Box (Ottawa: Conference Board of Canada, 2007) at 7, online: <www.caot.ca/pdfs/ Liability\%20Risks\%20report.pdf >. Various health professional groups have identified liability concerns as a barrier to interprofessional collaborative practice. See e.g. AD Taylor et al, "Community pharmacists' perceptions of their collaborative working relationships with physicians for drug therapy management: An exploratory study" (2008) 141:3 Can Pharmacists J 181.

24. Verena Schadewaldt et al, "Views and experiences of nurse practitioners and medical practitioners with collaborative practice in primary health care - an integrative review" (2013) 14:132 BMC Fam Prac 1, online: BioMed Central <www.biomedcentral. com/1471-2296/14/132>. See also Frances Legault et al, supra note 3; Deborah V Kelly et al, "Pharmacist and physician views on collaborative practice: Findings from the community pharmaceutical care project” (2013) 146:4 Can Pharmacy J 218. The Ontario College of Family Physicians advises: "liability issues are an impediment [to interprofessional collaboration] and need to be addressed because this limits physician's interest in exploring shared care relationships and limits the potential leadership roles that other professionals can assume." Ontario College of Family Physicians, Interprofessional Collaboration amongst Health Colleges and Professionals (Toronto: Ontario College of Family Physicians, 2008) at 8, online: 
that will guide judicial decisions in cases of alleged negligence involving health care delivered in a collaborative, team context.

This article focuses on civil liability principles and on statutory frameworks for health professional regulation. It is important to acknowledge that other areas of law will affect the transformation of Canadian health care systems to interprofessional team-based practice involving a range of health professionals working to optimal scopes of practice. For example, the Canada Health Act and provincial health insurance statutes establish legal frameworks for funding the services of specific professional groups under public health insurance. Health professions that have limited or no coverage under public insurance schemes may not be easily integrated into collaborative practice models with publicly insured practitioners. Legal challenges concerning funding and accessibility issues in health care have been litigated in Canada but are beyond the scope of this discussion. ${ }^{25}$

\section{STATUTORY REGULATION OF HEALTH CARE PROFESSIONALS: FLATTENING THE PYRAMID AND BROADENING SCOPES OF PRACTICE}

Health professions were historically viewed as forming a pyramid, with medical doctors at the top, assuming overall diagnostic and treatment responsibility:

In earlier years the medical team was fairly well delineated into easily identifiable groups. At the top were the physicians. Next came the nursing profession. The next strata consisted of the various technicians and technologists while the numerous assistants and orderlies directly involved in the provision of health care formed the base of the pyramid. ${ }^{26}$

Contemporary health care systems are shifting away from this traditional hierarchy that entrenched relationships of superiors and subordinates. Legislative reform now seeks to advance a flattened model of shared practice scopes without

$<$ ocfp.on.ca/docs/publications/interprofessional-collaboration-amongst-health-colleges-andprofessionals.pdf?sfvrsn $=2>$ [emphasis in original $]$.

25. For discussion, see e.g. Nola M Ries, "Charter Challenges" in Jocelyn Downie, Timothy Caufield \& Colleen M Flood, eds, Canadian Health Law \& Policy, 4th ed (Markham, Ont: LexisNexis Canada, 2011) 615; Donna Greschner, "Charter Challenges and Evidence-Based Decision-Making in the Health Care System: Towards a Symbiotic Relationship" in Colleen M Flood, ed, Just Medicare: What's In, What's Out, How We Decide (Toronto: University of Toronto Press, 2006) 42.

26. RA Davis, "Fresh thoughts on a growing problem: How we could arrest proliferation of allied health professions" (1971) 105:2 CMAJ 193 at 193. 
imposing a dominant pyramidal framework on the system. ${ }^{27}$ Many factors are driving these changes in Canadian health care, including government efforts to deliver better quality health care in cost-efficient ways, the professionalization of a broader range of health practitioner groups, and growing consumer demand for access to a wider range of services.

To achieve health system transformation, the Romanow Commission underscored the need to alter traditional approaches to regulating and deploying the health workforce:

Changes in the way health care services are delivered, especially with the growing emphasis on collaborative teams and networks of health providers, means [sic] that traditional scopes of practice also need to change. This suggests new roles for nurses, family physicians, pharmacists, case managers and a host of new and emerging health professions. ${ }^{28}$

This call for change implies that law reform is needed to impel health care reform. The scope of practice of health care providers is a core issue. The scope of practice refers to the activities that a professional is able and authorized to perform. Interprofessional teams necessarily involve practitioners from different disciplines—such as medicine, nursing, pharmacy, allied health, and psychology—who, in theory, bring complementary knowledge and skills to the provision of patient care. ${ }^{29}$

To establish a regulatory foundation to support the goals of interprofessional collaboration, many jurisdictions in Canada have reformed their health profession laws in recent years to establish a common legislative framework for health professions regulated in each province or territory, often referred to as "umbrella legislation." ${ }^{30}$ The umbrella legislation model involves the enactment of an overarching statute that provides a uniform regulatory framework for all professions governed by the legislation. Profession-specific laws or regulations operate in accordance with the umbrella statute. This approach stands in contrast to the traditional approach, in which separate statutes regulate each health profession and grant exclusive practice scopes that prohibit anyone other than a

27. Hierarchies may continue to exist, particularly when one profession has the authority to delegate or give directions to another groups, such as 'assistant' professions (e.g., physicians and physician assistants). The role of assisting professions is discussed below.

28. Supra note 4 at xxvii.

29. In practice, the activities a care provider performs may not extend to the full range of activities permitted by their profession's scope of practice and is determined by their work role in a specific health care setting.

30. Lahey, Lafferty \& Currie, supra note 19 at 188-89. 
member of the profession from providing specific services. ${ }^{31}$ Some jurisdictions have adopted a mixed model, with umbrella legislation governing some health professions, while others, typically traditional professions such as medicine, dentistry, and nursing, continue to be regulated under separate statutes. Table 1 summarizes the health professions legislation in all Canadian provinces and territories.

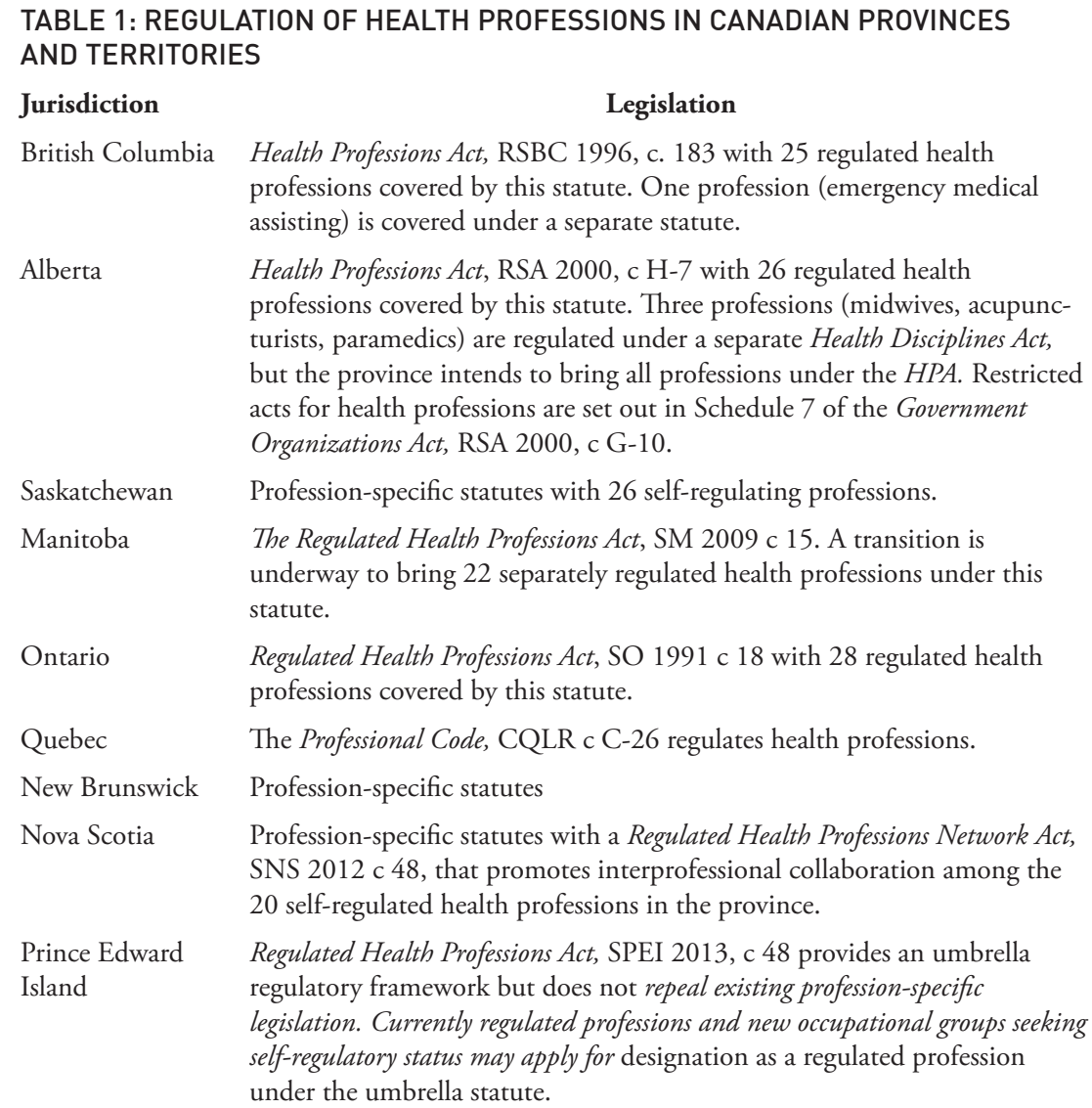

Alberta Health Professions Act, RSA 2000, c H-7 with 26 regulated health professions covered by this statute. Three professions (midwives, acupuncturists, paramedics) are regulated under a separate Health Disciplines Act, but the province intends to bring all professions under the HPA. Restricted acts for health professions are set out in Schedule 7 of the Government Organizations Act, RSA 2000, c G-10.

Saskatchewan Profession-specific statutes with 26 self-regulating professions.

Manitoba The Regulated Health Professions Act, SM 2009 c 15. A transition is underway to bring 22 separately regulated health professions under this statute.

Ontario Regulated Health Professions Act, SO 1991 c 18 with 28 regulated health professions covered by this statute.

Quebec The Professional Code, CQLR c C-26 regulates health professions.

New Brunswick Profession-specific statutes

Nova Scotia Profession-specific statutes with a Regulated Health Professions Network Act, SNS 2012 c 48, that promotes interprofessional collaboration among the 20 self-regulated health professions in the province.

Prince Edward Regulated Health Professions Act, SPEI 2013, c 48 provides an umbrella Island regulatory framework but does not repeal existing profession-specific legislation. Currently regulated professions and new occupational groups seeking self-regulatory status may apply for designation as a regulated profession under the umbrella statute.

31. Ibid 


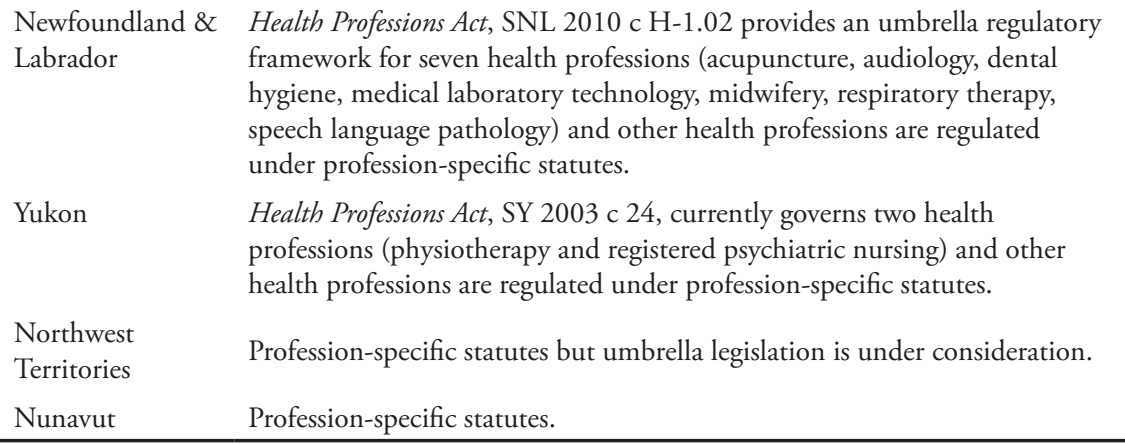

The move to umbrella legislation alters scope-of-practice statements to provide non-exclusive and non-exhaustive descriptions of each regulated profession's activities and areas of professional practice. The scopes of practice of regulated professions may have overlapping or shared activities. ${ }^{32}$ As the Government of Alberta explains: "No single profession has exclusive ownership of a specific skill or health service and different professions may provide the same health services." ${ }^{33}$ Restricted or controlled practice areas remain, but these constitute a narrowly defined list of higher risk activities that may only be performed by members of specific regulated health professions that have the training and skills to perform those acts. The same restricted activities may be granted to more than one profession and not all professions will be granted restricted activities. This legislative reform breaks down traditional silos of

32. See British Columbia Ministry of Health, Scope of Practice Reform, online: Government of British Columbia <www2.gov.bc.ca/gov/content/health/practitioner-professional-resources/ professional-regulation/scope-of-practice-reform>. The Government of British Columbia describes this approach:

Scope of practice statements are the concise descriptions, in broad, non-exclusive terms, of each regulated profession's activities and areas of professional practice. These statements describe in general what each profession does and how it does it. They are not exhaustive lists of every service the profession may provide, nor do they exclude other regulated professions or unregulated persons from providing services that fall within a particular profession's scope of practice.

33. Alberta Health, Regulated health professions, online: Government of Alberta <www.health. alberta.ca/professionals/regulated-professions.html>. 
practice and recognizes broader and shared areas of professional competence that traverse disciplinary boundaries. ${ }^{34}$

\section{A. INTERPROFESSIONAL COLLABORATION AS A STATUTORY OBJECTIVE}

Health professions statutes in some provinces have been amended to make explicit statements about interprofessional collaboration as the desired model of health care delivery, to confer a duty on regulatory colleges to collaborate with other professions, and to promote collaborative practice among regulated professionals. For example, Ontario's Regulated Health Professions Act states that one of the objects of a health profession college is: "To develop, in collaboration and consultation with other Colleges, standards of knowledge, skill and judgment relating to the performance of controlled acts common among health professions to enhance interprofessional collaboration, while respecting the unique character of individual health professions and their members." ${ }^{35}$ Similarly, British Columbias Health Professions Act describes the role of a college in promoting and enhancing "interprofessional collaborative practice between its registrants and persons practising another health profession." ${ }^{36}$ Prince Edward Island's umbrella Regulated Health Professions Act has similar language. ${ }^{37}$ Interestingly, the Act underscores the significance of interprofessional collaboration as a health policy objective by stating that one of the factors the government will consider in recognizing a new health profession is "the extent to which regulation of the health profession is likely to enhance inter-professional collaboration..." 38

To meet these legislative mandates, regulatory colleges are adopting various policies and programs to advance interprofessional collaboration. In Ontario, for instance, regulatory colleges must implement quality assurance programs that include continuing education and professional development to promote

34. The Government of British Columbia explains the rationale for this regulatory shift:

This approach abandons the historical notion of professional exclusivity in which legislation prohibits any person other than a member of the profession from performing certain services or procedures, except where another profession is also specifically authorized in legislation to perform them. Under the new model, many aspects of the scope of practice of each regulated profession may overlap, or be shared, with those of other regulated professions... (British Columbia Ministry of Health, supra note 32).

35. Regulated Health Professions Act, SO 1991, c 18, Schedule 2, s 3(1)(4.1) [RHPA].

36. Health Professions Act, RSBC 1996, c 183, s 16(2)(k)(i-ii).

37. Regulated Health Professions Act, SPEI 2013, c 48, s 4(2)(h). The provision states that one of the objects of a regulatory college is "to promote inter-professional collaboration with other colleges."

38. Regulated Health Professions Act, PEI Reg EC2013-829, s 5(g). 
collaborative practice for regulated professionals. ${ }^{39}$ Some colleges have developed practice standards and position statements that give guidance to members working in interprofessional collaborative contexts. ${ }^{40}$ In some cases, these statements have been developed jointly between regulatory colleges, an example of collaboration at the professional governance level. ${ }^{41}$

Taking a different approach, in late 2013, the Nova Scotia Legislature brought into force the Regulated Health Professions Network Act ${ }^{42}$ to promote collaboration among health professions. Premised on the view that voluntary actions among professions are preferred over compulsory approaches ${ }^{43}$ the legislation establishes a corporate body comprised of health profession regulatory authorities that is empowered to, among other things, collaborate in managing

39. RHPA, supra note 35, s 80.1(a)(i.1). The provision was brought into force in 2009. See e.g. Traditional Chinese Medicine Act, 2006, O Reg 28/13 (quality assurance program for traditional Chinese medicine); Kinesiology Act, 2007, O Reg 29/13 (quality assurance program for kinesiology).

40. See e.g. College of Nurses of Ontario, Practice Standard: Nurse Practitioner, October 2011 update (Toronto: College of Nurses of Ontario, 2011), online: <www.cno. org/Global/docs/prac/41038_StrdRnec.pdf>; College of Physicians and Surgeons of Ontario, Physician Working Relations with Pharmacists, online: <www.cpso.on.ca/ Policies-Publications/Positions-Initiatives/Physician-Working-Relations-with-Pharmacists>; College of Physicians and Surgeons of Ontario, Fostering Collaborative Relationships with Nurse Practitioners, online: <www.cpso.on.ca/Policies-Publications/Positions-Initiatives/ Fostering-Collaborative-Relationships-with-Nurse-P>.

41. See e.g. College of Physicians and Surgeons of Ontario, Position statement: Joint statement from the College and the College of Midwives of Ontario - CPSO and CMO Statement on Interprofessional Collaboration, online: <www.cpso.on.ca/policies-publications/ positions-initiatives/midwives>; College of Physicians and Surgeons of Ontario, Pharmacists Renewing andlor Adapting Prescriptions: A joint letter from the OCP, CPSO, OPA, and OMA (10 December 2012), online: <www.cpso.on.ca/CPSO/media/uploadedfiles/policies/policies/ Advisory_Notice_Renewing_Adapting_Prescriptions.pdf >.

42. SNS 2012, c 48 [RHPNA]. For elaboration on approaches to encouraging interprofessional collaboration, see William Lahey, "Interprofessionalism and Collaborative Self-regulation in the Health Professions: Two Variations on an Emerging Canadian Theme" in Stephanie Short and Fiona McDonald, eds, Health Workforce Governance: Improved Access, Good Regulatory Practice, Safer Patients (Surrey, England: Ashgate Publishing, 2012) 113.

43. For discussion, see William Lahey \& Katherine Fierlbeck, "Legislating collaborative self-regulation in Canada: A comparative policy analysis" (2016) 30:2 J Interprofessional Care 211. 
regulatory processes ${ }^{44}$ and facilitating the delivery of interprofessional care. The Act authorizes health professions with overlapping practice scopes to enter agreements, subject to Ministerial review, that serve as binding interpretations of their scopes of practice or to set out procedures for addressing scope of practice issues..$^{45}$ It also sets out a process for regulated health professions to seek modifications to their legislative scopes of practice. ${ }^{46}$ This legislative model is in the implementation phase and a mandatory review and report on the operation of the Act will occur in 2018-19.47

\section{B. EXPANDED SCOPES OF PRACTICE AND NEW PROFESSIONAL GROUPS}

The Romanow Report indicated the need for reforms to address the growing range of occupational groups in the health workforce: "The multiplicity of health care providers is both a tremendous resource and a challenge in terms of sorting out new models of primary health care, new roles and responsibilities, and more collaborative ways of working together." ${ }^{48}$ William Lahey and Katherine Fierlbeck echo this concern: "As the number of regulated health professions has proliferated, a regulatory landscape of legislated silos making functional engagement across professional boundaries difficult has resulted." ${ }^{49}$ Governments across Canada have engaged in law reform to support role changes within the health workforce, particularly to expand the scope of practice for groups that are already regulated and to recognize additional health professions.

The regulated health workforce has moved well beyond the more established occupations of medicine, nursing, optometry, pharmacy, and dentistry and now

44. Regulatory processes are defined to mean: "those processes and matters generally prescribed by a regulated health profession's governing statute to (i) establish the scope of practice of the profession, (ii) govern the registration or licensing of members of the profession, (iii) establish investigative and hearing processes for complaints involving members of the profession, (iv) address quality assurance matters for the profession, (v) govern appeals or reviews from any decisions made pursuant to the profession's governing statute, or (vi) regulate any other aspect of the profession..." RHPNA, supra note 42, s 3(w).

45. Ibid, s 17 .

46. Ibid, s 18; Regulated Health Professions Network Regulations, NS Reg 61/2014, s 3.

47. RHPNA, supra note 42, s 41. For further discussion of the Nova Scotia model, see William Lahey, "Legislating Interprofessional Regulatory Collaboration in Nova Scotia" (2013) 1:1 Health Reform Observer - Observatoire des Réformes de Santé 1. See also Nova Scotia Regulated Professions Network, online: <www.nsrhpn.ca/>; Health Law Institute, Collaborative Self-Regulation Project: Collaborative self-regulation of regulated health professions in Nova Scotia, online: Dalhousie University <www.dal.ca/faculty/law/hli/research/ collaborative-self-regulation.html>.

48. Supra note 4 .

49. Supra note 43 at 212. 
includes professionals in a wide range of categories, including allied health and rehabilitation-focused professions (e.g., physiotherapy, occupational therapy, speech pathology, audiology, clinical psychology, and dietetics) as well as complementary and alternative health professions (e.g., naturopathy, chiropractic, and traditional Chinese medicine). Within the established occupations and in newer professions, governments are recognizing new occupational roles. For example, the scope of practice of pharmacists has been expanded to encompass acts that were previously restricted to physicians. A majority of provinces and territories now permit pharmacists to provide emergency prescription refills, renew or extend prescriptions, change the dosage or formulation of a drug, and make a therapeutic substitution. ${ }^{50}$ Other legislative reforms have enabled pharmacists to prescribe drugs for minor, self-limiting conditions, order lab tests and interpret results, and administer drugs, including vaccines, via injection. ${ }^{51}$

All Canadian jurisdictions have implemented legislation to recognize nurse practitioners (NPs), who are registered nurses with additional educational qualifications and experience. ${ }^{52}$ Although legislated NP scopes of practice vary across the country, in most cases NPs are legally permitted to establish and communicate diagnoses to patients, order certain tests, and prescribe some drugs. Interestingly, regulatory reform concerning the scope of NPs has helped address legal ambiguities identified in some jurisdictions. For example, prior to the formal regulation of NPs, registered nurses practicing in British Columbia, especially rural and remote areas, performed acts outside their legislated scope of practice. For instance, they diagnosed and treated sexually transmitted infections as well as minor conditions, and provided contraceptive pills. These acts were authorized (albeit, not always with legally defensible authority) through means such as delegation from a physician to a nurse, institutional protocols, or medical orders after the fact. These mechanisms raised concerns, however, insofar as "they blurred the lines of accountability and responsibility." 53 The enactment of the Nurses (Registered) and Nurse Practitioners Regulation in 2005 provided legal clarity on the roles and scopes of practice of nursing professionals in the province.

50. See Canadian Pharmacists Association, Pharmacists' Scope of Practice in Canada (Ottawa: Canadian Pharmacists Association, 2016), online: <www.pharmacists.ca/cpha-ca/assets/File/ Scope\%20of\%20Practice\%20in\%20Canada_JULY2016.pdf>.

51. Ibid.

52. Janis Hass, "Nurse practitioners now able to work across Canada" (2006) 174:7 CMAJ 911 at 911.

53. Jo Wearing \& Veronica Nickerson, "Establishing a Regulatory Framework for Certified Practices in British Columbia” (2010) 1:3 J Nursing Reg 38 at 38. 
In some provinces, recent legislative changes have recognized certain assisting occupational groups. Physician assistant (PA) roles are increasing ${ }^{54}$ and two provinces-Ontario and Alberta-have recently considered whether PAs should have legal status as independently regulated health professions. PAs work within a practice scope negotiated with a supervising medical doctor. In jurisdictions where they are legally recognized, PAs are registered to practice by the provincial College of Physicians and Surgeons. ${ }^{55}$ The Alberta government indicated an interest in regulating PAs, ${ }^{56}$ but Ontario's Health Professions Regulatory Advisory Council (HPRAC) recommended against independent regulation of PAs largely because it accepted that the current model of medical supervision protects patient safety. ${ }^{57}$ HPRAC supported mandatory registration of PAs through the College of Physicians and Surgeons, suggesting that "[i]nterprofessional collaboration between PAs and other health professionals [will] be enhanced as a by-product of the registry, through encouraging the growth of the profession in Ontario and by instilling confidence among regulators and the practice community about PAs' qualifications." 58

Pharmacist technicians are another occupational group whose role is expanding; with technicians performing acts related to preparing and processing drug prescriptions, pharmacists may allocate their time to more complex patient care activities. In recent years, a number of provinces have adopted new regulatory provisions concerning the practice of pharmacy technicians, including Alberta

54. Physician assistants have a long history of providing medical services in the Canadian Forces and the role is slowly gaining ground in civilian health care delivery. For discussion, see e.g. Hans W Jung, "The birth of physician assistants in Canada" (2011) 57:3 Can Fam Physician 275; Ian W Jones \& Roderick S Hooker, "Physician assistants in Canada: Update on health policy initiatives" (2011) 57:3 Can Fam Physician e83. Trained with a medical model of health care provision, the professional competencies of physician assistants include taking patient histories, ordering diagnostic tests and prescribing treatments.

55. In 1999, Manitoba was the first province to recognize "clinical assistants" in regulations under its Medical Act and the title of "physician assistant" was added in 2009 amendments. The same year, New Brunswick amended its Medical Act to allow registration of PAs. The Alberta College of Physicians and Surgeons passed a bylaw in 2010 to allow PA registration.

56. For a summary of legislative developments, see the Canadian Association of Physician Assistants, Legislation, online: <capa-acam.ca/pa-employers/legislation/>.

57. Ontario Health Professions Regulatory Advisory Council, The Health Profession Assistant: Consideration of the Physician Assistant Application for Regulation (Toronto: Health Professions Regulatory Advisory Council, 2012), online: <www.hprac.org/en/reports/resources/ PA_ENG_VOL_1_E_FILE-COMPLETEFINALAODA-s_nosignatures.pdf >.

58. Ibid at 2 . 
and British Columbia in 2011, ${ }^{59}$ and Nova Scotia in 2013. ${ }^{60}$ Dental hygienists in some jurisdictions have been granted expanded authority to provide low-risk oral care services (e.g., teeth cleaning) independently, while in others the hygienist role continues to require supervision by a dentist. ${ }^{61}$ Complementary and alternative health care practitioners, such as naturopaths and massage therapists, are also increasingly gaining recognition as regulated health professions, and integrative health clinics that involve collaboration between allopathic and alternative care providers are being established. ${ }^{62}$

While health profession statutes may be reformed to promote collaborative team models in which professions work to broader scopes, older statutes may structure health care environments in ways that work against this modern approach. ${ }^{63}$ Governments committed to law reform to promote interprofessional collaboration must undertake a comprehensive review of legislation and update older statutes that reflect outmoded models of health service delivery. For example, some commentators point out that Hospitals Acts that require physician orders for certain health care procedures conflict with updated scope of practice statements for other professional groups, such as nurses, that authorize a broader range of

59. Pharmacists Regulation, BC Reg. $417 / 2008$ amended by BC Reg $211 / 2010$ (recognition of pharmacy technicians effective 1 January 2011); Pharmacists and Pharmacy Technician Profession Regulation, Alta Reg 129/2006, as amended.

60. Pharmacy Practice Regulations, NS Reg 258/2013. For links to all pharmacy regulatory authorities in Canada and rules regarding pharmacy technicians, see Canadian Council for Accreditation of Pharmacy Programs, "Resources", online: "Getting Registered in a Province of Canada as a Pharmacy Technician" <http://ccapp-accredit.ca/resources/>.

61. For a comprehensive overview of dental hygiene regulation across Canada, see Canadian Dental Hygienists Association, Dental Hygiene Regulation: A Comparison (Canadian Dental Hygienists Association, 2013), online: <www.cdha.ca/pdfs/profession/ RegulatoryComparisonCharts_final.pdf>.

62. Complementary/alternative medicine and interprofessional collaboration are beyond the scope of this article. For discussion, see e.g. Daniel Hollenberg \& Ivy Lynn Bourgeault, "Linking integrative medicine with interprofessional education and care initiatives: Challenges and opportunities for interprofessional collaboration" (2011) 25:3 J Interprofessional Care 182; Nola M Ries \& Katherine J Fisher, "The Increasing Involvement of Physicians in Complementary and Alternative Medicine: Considerations of Professional Regulation and Patient Safety" (2013) 39:1 Queen's LJ 273.

63. Sandra Regan et al, "Legislating interprofessional collaboration: A policy analysis of health professions regulatory legislation in Ontario, Canada” (2015) 29:4 J Interprofessional Care 359 at 362. 
actions without physician orders. ${ }^{64} \mathrm{~A}$ study of nurse practitioners transitioning into practice in Ontario revealed examples of legislative, policy, and workplace barriers that prevent NPs from working to the full scope of their professional competence. ${ }^{65}$ For instance, if drug prescriptions and referrals ordered by nurse practitioners are not recognized, either by legislation or in organizational policies, inefficient duplication in service provision occurs, as doctors are required to make those orders. ${ }^{66}$

\section{SUPPORTING OPTIMAL SCOPES OF PRACTICE}

Laws that preserve rigid professional boundaries and traditional hierarchies limit innovative models of health service delivery. ${ }^{67}$ Professional territorialism is a

64. Ibid. See College of Nurses of Ontario, Practice Guideline: Authorizing Mechanisms, Updated 2015, (Toronto: College of Nurses of Ontario, 2015), online: <www.cno.org/Global/docs/ prac/41075_AuthorizingMech.pdf> at 6 . The College of Nurses of Ontario also notes this restriction:

Although RNs and RPNs have the legal authority to initiate a controlled act, in practice the opportunity to initiate may be limited by other legislation or practice-setting policies. A specific facility may not permit its nursing staff to initiate controlled acts. For example, RNs and RPNs cannot initiate treatments in a hospital setting because the Public Hospitals Act grants only physicians, NPs, midwives and dentists the authority to order treatments.

65. Maureen Sullivan-Bentz et al, "Supporting primary health care nurse practitioners' transition to practice” (2010) 56:11 Can Fam Physician 1176.

66. Various studies have noted inefficiencies with nurse practitioners having to seek prescription approval from a physician. See e.g. Ann Long et al, "Has the introduction of nurse practitioners changed the working patterns of primary care teams?: A qualitative study" (2004) 5 Primary Health Care Research \& Development 28. For instance, one medical doctor interviewed in this study commented that nurse practitioners have advanced training and "the whole prescribing area needs to be addressed, it's crazy that she has to run to us and stand outside my door waiting for me to come out so that I can sign a script. It is an absurdity that she can't prescribe antibiotics." (Ibid at 35).

67. Nicholas Chadi makes this point forcefully, writing that "the rigidity of healthcare structures and scope-of-practice rules ... represents an ominous barrier to increasing productivity in healthcare. ... [T] he taboo surrounding physicians' rigid scopeof-practice should be broken; this would promote a stronger and more integrated multidisciplinary approach to medicine." Chadi, supra note 22 at 44. 
well-identified barrier to interprofessional collaboration. ${ }^{68} \mathrm{Law}$ reform to challenge entrenched patterns is a necessary step in overcoming this barrier. Maintaining rigid boundaries may result in situations where care providers perform activities outside their legislated scope of practice, but without clear legal authority. These situations are undesirable both for professionals and their patients. Legislative innovation-notably, to broaden scopes of practice to authorize practitioners to perform acts they have not previously been lawfully permitted to performprovides an enabling macro-level environment for interprofessional collaboration. Once this environment is in place, other factors influence the extent to which individual practitioners are able to collaborate effectively and work to an optimal scope of practice in which teams are organized and function in ways that make best use of their members' training, skills, and experience. ${ }^{69}$ These factors include other macro-level factors, such as compensation and health insurance schemes, meso-level factors, such as organizational policies that integrate professions from multiple disciplines into a team, and micro-level factors, such as practitioners' trust in the competence of their colleagues to deliver care at the higher end of their scope of practice. $^{70}$

Existing policies and practices based on traditional models of power and expertise may be slow to change. Quarrels over professional turf are a barrier to effective collaboration, particularly if health profession leaders focus on "[scope of] practice disputes and turf protection rather than the exploration

68. See e.g. Sullivan-Bentz et al, supra note 65 at 1179 . Two experts in the law and politics of collaborative health care observe that "one official study after another had concluded that integrated care is complicated or prevented by occupational turf wars in which one of the fronts is the definition and application of interacting scopes of practice." See William Lahey \& Katherine Fierlbeck, "From Circling the Wagons to Building the Bridges: Intersectoral Governance and Collaborative Self-Regulation in Health Care" (Article delivered at the First International Conference on Public Policy, Grenoble, France, 26-28 May 2013) at 9, online: International Conference on Public Policy <www.icpublicpolicy.org/IMG/pdf/ panel_65_s2_lahey.pdf >.

69. It is said that "working to optimal scope means achieving the most effective configuration of professional roles as determined by other health care professionals' relative competencies." Canadian Academy of Health Sciences, supra note 9 at 22.

70. For the argument that other factors are important to facilitating interprofessional collaboration, see e.g. Ontario College of Family Physicians, supra note 24 at 14 . The Ontario College of Family Physicians asserts that governments "should not place undue emphasis on the value of legislation and regulation at the College level to achieve IPC; the greatest gains will be achieved through a comprehensive action plan that begins by addressing primary enablers such as compensation and funding, interprofessional education/teaching/ training, organizational supports and liability." 
of collaborative and interdisciplinary approaches." ${ }^{\text {"11 }}$ Studies of the experiences of health professionals who have transitioned to collaborative practice models highlight ways to overcome these types of barriers. ${ }^{72}$ Factors that support such a transition include education and training to help professionals understand one another's role, designation of a leader responsible for coordinating team activities, and organizational procedures that facilitate regular communication among practitioners. ${ }^{73}$

Governments may engage in scope-of-practice reforms without necessarily moving to an umbrella regulatory framework. Where separate statutes regulate each profession, the scope of practice for a particular profession may be amended to expand the legally permissible acts a member may perform. ${ }^{74}$ However, a clear advantage of adopting an umbrella model is that it establishes a uniform framework for all regulated health professions and avoids a patchwork approach to regulatory reform.

\section{THE LEGAL LIABILITY OF HEALTH PROFESSIONALS}

Legal liability rules are another major influence on interprofessional collaboration. This Part discusses legal liability topics of particular salience to a model of health care practice involving teams of health professionals working collaboratively and, increasingly, with expanded and overlapping scopes of practice. Specifically, this Part summarizes the Canadian case law dealing with negligence claims

71. Lynn Jansen, "Collaborative and Interdisciplinary Health Care Teams: Ready or Not?" (2008) 24:4 J Professional Nursing 218 at 222.

72. See e.g. Frances Legault et al, supra note 3; Sullivan-Bentz et al, supra note 65; Patricia Bailey, Linda Jones \& Daniel Way, "Family physician/nurse practitioner: stories of collaboration" (2006) 53:4 J Advanced Nursing 381.

73. Canadian Academy of Health Sciences, supra note 9 at 59.

74. For discussion of reforms to pharmacists' scopes of practice in Ontario, which has umbrella legislation, and Saskatchewan, which does not, see e.g. Olena Kapral, "The Enhancement of the Scopes of Pharmacists' Practice: A Comparative Analysis of the Regulatory Frameworks in Saskatchewan and Ontario" (Presentation delivered at the Annual Canadian Association of Health Services and Policy Research Conference, Toronto, 13 May 2014). A copy of this presentation is on file with the author. 
that relate to health care delivered in an interprofessional team context. ${ }^{75}$ Concerns about legal liability stem from the fact that more professionals from different disciplines are involved in a patient's care, thus giving rise to risks in relation to communication among multiple practitioners and responsibility for the management and delivery of the patient's care. A Canadian report on legal liability issues in interdisciplinary health care practice commented that "insurers and professional protective organizations are concerned about the need to ensure effective and efficient communications, and to establish clear roles that are aligned with provincially legislated and regulated scopes of practice." ${ }^{76}$ It noted "the importance for health professionals to be clear about who does what when their responsibilities overlap, so that patient management tasks won't 'slip between the cracks."'77

Interprofessional collaboration is often described as involving "shared responsibility ... [and] both team and individual accountability for client care,"78 but how is shared responsibility addressed when patient harm occurs and the legal liability of health care team members must be determined? As this section discusses, the approach of shared patient care responsibility in collaborative practice does not translate to a default sharing of legal culpability if a patient is harmed in the course of care. A key finding of this jurisprudence review is that Canadian courts recognize changing models of health care delivery and examine each situation of alleged negligence to determine if and how the actions of individual practitioners fell below the expected standard of care.

\section{A. THE TEAM-BASED NATURE OF HEALTH CARE DELIVERY}

Multiple cases have remarked on the team-based nature of health service delivery and emphasized that health care professionals must be able to rely on others working in the system to perform their roles appropriately. In general, it is reasonable for professionals to expect that systems will function effectively and "to rely on colleagues and co-workers and on established procedures that have

75. A search of reported decisions was carried out in the CanLII database using various combinations of search terms: 'multidisciplinary', 'interdisciplinary', 'collaborative', 'collaboration', 'team', 'scope of practice', 'negligent', 'negligence' and 'liability'. Relevant cases identified through this search were noted up and earlier cases referred to in the decisions were retrieved. Specific date limits were not imposed on the searches and the analysis ultimately included decisions from the 1980s to present. Earlier cases were used as a foundation upon which the development of legal rules could be traced.

76. Conference Board of Canada, supra note 23 at 32.

77. Ibid.

78. College of Nurses of Ontario, supra note 40 at 12. 
functioned well in the past." ${ }^{\prime 9}$ In Anderson $v$ Salvation Army Maternity Hospital, a Nova Scotia case, Justice Nunn commented:

... there was a system in effect within the hospital under which all those involved in the hospital worked and carried out the duties and responsibilities of their professions. The only occasion on which this system failed was on this one occasion. It had not failed before or after...

To hold that reliance on a system such as this in the normal course of the practice of a doctor's profession could render him liable in negligence, absent other factors, would be absolutely catastrophic in the provision of services in a hospital. Hospital rules and procedures are generally devised by those concerned to assure the highest standards of care is $[s i c]$ given in the most practical and efficient manner.

If something in the system fails, through negligence, then liability attaches, but to the one who was negligent. ${ }^{80}$

Moreover, courts recognize that the team-based model demands reliance on all practitioners working to their appropriate practice scope and standard:

The health care system in Canada mandates that these professionals work as a team with each individual having a role in the provision of care to a [patient]. Each person must carry out their role within their appropriate standard of care and each of these professionals is entitled to rely upon (and must rely upon) the others to fulfill their respective individual responsibilities. ${ }^{81}$

To elaborate further on this principle, it is worth extracting the following judicial quotation at length:

...one of the hallmarks of the Canadian health system... is that those involved in obstetrics work as a team and that the interaction between members of that team is vitally important particularly in terms of reliance on one another for the provision of accurate information. ... our system of health care, with its obvious concerns for patient care as well as its defined budget considerations, could not function in any other way. We simply do not have the financial resources to enable every professional to double check the work of other professionals and because each professional within the obstetrical team has a defined role, it is essential that each

79. Bush v Friedman, 2011 ONSC 4988 at para 108, 208 ACWS (3d) 208.

80. (1989), 18 ACWS (3d) 510, 1989 CarswellNS 157 (WL Can) at paras 124-27 (NSSC (TD)).

81. Bauer $v$ Seager et al, 2000 MBQB 113 at para 43, 98 ACWS (3d) 714. For other cases on the team approach to health care, see e.g. Geurineau v Dr Seger et al, 2001 BCSC 291, 103 ACWS (3d) 78; Misericordia Hospital v Bustillo, 1983 ABCA 4, [1983] AJ No 270 (QL) (team care in surgical context); Atcheson $v$ College of Physicians \& Surgeons (1994), 148 AR 395, 18 Alta LR (3d) 105 (QB) (doctor and nurse collaboration). 
person's role be carried out within a standard of care and training appropriate to the professional involved. ...

We cannot expect the staff doctor to question the professional capabilities of others on the obstetrical team. The same would clearly apply to all other units within a hospital of the same nature. The staff obstetrician should be entitled to rely upon the information being given to him or her by the staff nurse on the understanding that the nurse, assigned by the hospital to these duties, has been properly trained, is sufficiently experienced and knows what he or she is doing at all times within the scope of his or her professional responsibilities. ${ }^{82}$

Just as team-based collaboration has been a hallmark in modern obstetrical care, the contemporary emphasis on interprofessional care brings this model to many other areas of health service delivery. The point that the health care system will not function if professionals cannot rely on other care providers takes on even greater salience with governmental reforms to advance the collaborative care model and expand the roles of a greater variety of health professionals. Yet, appropriate reliance on other professionals does not mean overreliance. Health practitioners must still discharge duties reasonably expected of them. For example, when a health care provider sees a new patient referred from another professional, she must fulfill a legal duty to take the patient's history, discuss the patient's current symptoms, and "explore why the patient has come to see her." 83 She may not simply rely on the clinical records that accompany the referral.

As a clarification of the general position that a health care provider is entitled to rely on interprofessional team members, courts have instructed that if a practitioner knows or should know that another professional has failed to meet his or her obligations, the practitioner may have a duty to question that colleague's practice. For instance, where incompetent practice is "clear and obvious,"

82. Granger (Litigation Guardian of) v Ottawa General Hospital (1996), 7 OTC 81, 63 ACWS (3d) 1278 (Ont Gen Div). Interestingly, the Canadian Nurses Protective Society cites this case as authority for the proposition that "it has not been deemed fair that if a member of the team is proved negligent that the other team members are held accountable by virtue of being fellow team members." See Canadian Nurses Protective Society, Collaborative Practice: Are Nurses Employees or Self-Employed? (August 2006), online: Canadian Nurses Protective Society $<$ www.cnps.ca/index.php?page $=40 \# 3>$.

83. Preston et al $v$ Chow et al, 2007 MBQB 318 at para 84, 211 DLR (4th) 756. In this case, a doctor was found negligent for failing to appropriately manage an active herpes virus infection in a pregnant patient, which led to severe neurological injury in the newborn who developed herpes encephalitis. The pregnant patient saw the doctor to request an STD screen, but the doctor did not ask the patient for any details about her concerns about having been exposed to a sexually transmitted infection. 
a health care professional may have "a positive duty to intervene." ${ }^{44}$ Courts have considered negligence claims in cases where a health practitioner referred a patient to another professional known to have a history of incompetent practice. In a case involving an obstetrician and gynaecologist with an "alarmingly high complication rate," a court allowed negligence claims to proceed against other doctors who referred patients to the specialist when his "pattern of repetitive negligence was well known to" them. ${ }^{85}$ Simply put, turning a blind eye to the substandard practices of another practitioner does not advance safe and effective interprofessional collaboration.

\section{B. STANDARD OF CARE AND RESPONSIBILITY FOR NEGLIGENT ACTS}

In assessing allegedly negligent actions, a court considers the conduct expected of practitioners "who possess a reasonable level of knowledge, competence and skill expected of professionals in Canada." ${ }^{\prime 6} \mathrm{~A}$ health care professional must meet the standard of "a prudent and diligent" practitioner of the same profession. ${ }^{87}$ This means, for example, that a medical doctor must meet the standard expected of a prudent medical doctor and a physiotherapist must meet the standard of a prudent physiotherapist. ${ }^{88} \mathrm{~A}$ practitioner who represents himself as a specialist

84. See Skeels (Estate of) v Iwashkiw, 2006 ABQB 335 at paras 92-95, 63 Alta LR (4th)

26. The court cites the following ruling: Serre $v$ DeTilly (1975), 8 OR (2d) 490,

58 DLR (3d) 362 (SC).

85. Williams $v$ Wai-Ping (2005), 139 ACWS (3d) 583, [2005] OJ No 1940 (QL) (Ont SC).

86. ter Neuzen $v$ Korn, [1995] 3 SCR 674 at para 33, 105 WAC 241 [ter Neuzen].

87. Ibid. See also Crits v Sylvester, [1956] OR 132, 1056 CarswellOnt 90 (WL Can) at para 13

(CA); affd [1956] SCR 991, 5 DLR (2d) 601.

88. See Kim $v$ Choi, 2012 ONSC 6627 at paras 73-74, 223 ACWS (3d) 885:

In a medical negligence action, the central issue is whether or not the physician met the appropriate standard of care. To succeed, a plaintiff must lead expert evidence of a physician practicing in the defendant's area of medicine who attests to the defendant's failure to meet the standard of care required in such circumstances. ... The same principles apply in actions brought against other health professionals including physiotherapists, nurses, massage therapist, social workers, or chiropodists. For a plaintiff to succeed he or she must lead expert evidence from the appropriate professional that confirms that the professional being sued has not met the standard of care required. [internal citations omitted]

See also Briante (Litigation guardian of) v Vancouver Island Health Authority, 2014 BCSC 1511 at para 264, 14 CCLT (4th) 204 [Briante]. The court states:

The traditional standard of care for a physician is simply stated: the doctor is bound to exercise that degree of care and skill which could reasonably be expected of a normal, prudent practitioner of the same experience and standing. ... That standard applies equally to other medical professionals; a psychiatric nurse must meet the standard of care expected of a normal, prudent psychiatric nurse, and so on. 
"must exercise the degree of skill of an average specialist in his field." ${ }^{89}$ A court applies a standard of reasonableness, not perfection or infallibility, and recognizes the complexities and pressures of health service delivery. ${ }^{90}$

Courts have emphasized that each health profession has its own practices and competency standards and that these standards are a starting point for considering legal duties: "Each member of the healthcare team must carry out their role within their appropriate standard of care and each of these professionals is entitled to rely upon the others to fulfill their respective individual responsibilities." ${ }^{\prime 1}$ Canadian legal precedent does not support holding a health practitioner to a standard applicable to a different health professional group where that practitioner has acted reasonably within their own scope. In a labour arbitration case that considered the regulation of nurse practitioners and an expanded scope of practice for that occupational group, the arbitrator commented that this new professional category of nurse practitioner "blurred the line that had historically divided nursing care, provided by nurses, and medical care, provided by physicians." ${ }^{\text {92 }}$ He went on to state:

...the province has moved the line to permit some registered nurses to perform tasks formerly beyond their scope of practice. The legislation has expanded the historical role of the nurse. It did not ... [bring] nurse practitioners under the regulatory umbrella of the College of Physicians and Surgeons. ... It is a nursing function to engage in the additional controlled acts authorized [by the regulatory changes]. ${ }^{93}$

89. ter Neuzen, supra note 86 at para 33. See also Wilson v Swanson, [1956] SCR 804, $5 \operatorname{DLR}(2 \mathrm{~d}) 113$.

90. Ellen I Picard \& Gerald B Robertson, Legal Liability of Doctors and Hospitals in Canada, 4th ed (Toronto: Thomson Canada, 2007). See also Bush v Friedman, 2011 ONSC 4988, 208 SCWS (3d) 208. Justice Reilly observed that the legal standard requires that a health professional deliver reasonably prudent care, not 'gold standard' care that might, in retrospect, have been the ideal course of action in a particular situation.

91. Ferguson $v$ Steel, 2007 ABQB 596 at para 143, 162 ACWS (3d) 148 [Ferguson]. See also Gemoto $v$ Calgary Regional Health Authority, 2006 ABQB 740 at para 306, 153 ACWS (3d) $468[$ Gemoto]. The court states that "[n]urses are independent professionals with their own standards of competence. They have a duty to use their skills, knowledge and judgment in making appropriate assessments of patients and to communicate accurately those assessments to physicians."

92. St Joseph's Hospital (Elliot Lake) v Ontario Nurses Association (2003), 121 LAC (4th) 201, 2003 CanLII 71136 at para 42 (OLRB) [Elliot Lake]. This passage was cited with approval in Ontario Nurses' Associationv The Credit Valley Hospital and Trillium Health Centre, 2012 CanLII 81621 (OLRB).

93. Elliot Lake, ibid. 
This statement clarifies that practitioners performing functions within their (legally expanded) professional scope are to be judged against the standards expected of their own profession. A nurse practitioner-even "a highly trained nurse practitioner ... [who] is as close to being a doctor as is possible for a nurse" 1 -is not judged against the standards expected of a medical doctor. ${ }^{95}$ Evidence of professionals from other disciplines may be relevant, however, in assessing whether the appropriate standard of care was met: "Because of the 'team approach' to modern health care delivery, evidence of both nurses and physicians is admissible in determining whether the nursing standard of care was met." ${ }^{16}$ As noted above, two or more health professional groups may jointly develop standards of practice. Experts from professional groups that follow the standards may give evidence about them in court. Standards of practice for interprofessional collaboration produced by regulatory bodies have legal significance: A failure to comply with such standards may constitute professional misconduct or be used as evidence in a negligence claim that the professional breached the expected standard of care. ${ }^{97}$

The Canadian Medical Protective Association, a mutual defence organization for physicians throughout Canada, has issued policy statements affirming that each regulated health professional group has its standards of practice and responsibility for its own actions: "In an interprofessional model, every member of the care team is accountable for the care he or she provides and may also be held accountable for his or her role in the outcomes. As a result, each professional owes a separate duty to the patient within his or her scope of practice. There is an established legal precedent that confirms health professionals are not to be held directly liable for the acts of others." 98

94. Gemoto, supra note 91 at para 324.

95. With respect to nurse practitioners, the Ontario College of Nurses issued new Standards of Practice for Nurse Practitioners in 2011. College of Nurses of Ontario, supra note 40.

96. Milne v St. Joseph's Health Centre (2009), 180 ACWS (2d) 981, 2009 CanLII 51196 at para 74 (Ont Sup Ct). See also Gemoto, supra note 91 at para 324. In that case the court accepted that "a highly trained nurse practitioner [who] is as close to being a doctor as is possible for a nurse" may give evidence as to the standard of care of an emergency nurse who does not have the additional training and experience as a NP.

97. Koch v Brydon, 2008 SKQB 464 at paras 20-23, 173 ACWS (3d) 626; Spillane (Litigation Guardian of) $v$ Wasserman (1992), 13 CCLT (2d) 267, 37 ACWS (3d) 412 (Gen Div).

98. Canadian Medical Protective Association, The new reality: Expanding scopes of practice (March 2010), online: <oplfrpd5.cmpa-acpm.ca/-/the-new-reality-expanding-scopes-of-practice>. This document continues on to note: "However, as interprofessional practices often involve multiple encounters, events and conditions treated by multiple health professionals over a period of many years, it is often not straightforward to determine individual responsibility for outcomes." 
Yet in a team context, some practitioners, particularly medical doctors, express concern about exposure to legal liability for the actions of other professionals. For example, the Ontario College of Family Physicians comments that "a key concern among physicians is the issue of who would ultimately be responsible and held accountable if an adverse event were to occur as the result of interprofessional care. Physicians will not enter into situations that leave them exposed to medical-legal risk." "99 Existing case law does not, however, support the notion that based on statutory scope of practice alone, a doctor should be legally liable for the acts of other regulated professionals. ${ }^{100}$

To illustrate, in one court case, a doctor gave evidence concerning a physician's responsibility for patient care:

The admitting physician remains the responsible physician for the care of that patient unless he, or she, goes away and signs out to another physician. ... In a university teaching hospital the care of the patient is by a team comprised of responsible physicians and residents, interns, fellows, medical students, elective students, but the responsibility lies with the attending physician. ${ }^{101}$

The judge dealt with this statement as follows:

I do not see this evidence as representing a legal opinion respecting a physician's liability for the action of others. ... If it was intended as a statement that a physician is legally responsible for every member of the team who may be negligent, it is wrong in law. ${ }^{102}$

Each team member must each fulfill his or her respective duties in relation to patient care, communication, and documentation. A recent British Columbia case, Briante $v$ Vancouver Island Health Authority, considered the liability of a registered psychiatric nurse (RPN) and an emergency physician in a situation where a man seriously harmed himself after being released from hospital. ${ }^{103}$ The patient and his family argued he should have been referred immediately for an urgent psychiatric consultation. The court considered the collaborative care model in place at the hospital to handle psychiatric emergencies. The RPN held

99. See e.g. Ontario College of Family Physicians, supra note 24 at 8 . The report notes that: "a key concern among physicians is the issue of who would ultimately be responsible and held accountable if an adverse event were to occur as the result of interprofessional care. Physicians will not enter into situations that leave them exposed to medical-legal risk."

100. An exception may be situations where a doctor has specific legal obligations as an employer and is held accountable under the doctrine of vicarious liability.

101. Kielley v General Hospital Corp (1997), 150 Nfld \& PEIR 163, 1997 CanLII 14701 at para $30(\mathrm{CA})$.

102. Ibid at para 31 [emphasis added].

103. Briante, supra note 88 . 
primary responsibility to collect information about a presenting patient, then to provide it to the emergency doctor, who would use that information in assessing the patient and determining a treatment plan. Several expert witnesses described this collaborative approach as enabling better patient care "as the nurse has more time to spend with the patient and the nurse has more specific psychiatric training than the emergency room physicians." ${ }^{104}$ Regrettably, in this particular case, the RPN failed to collect adequate information and discuss the patient's situation fully with the emergency physician. In turn, the doctor did not take sufficient care to consider all available information about the patient and to be alert to discrepancies between her assessment and that of the RPN. ${ }^{105}$

The court stated:

Where the patient is seen by a treatment team-nurses, doctors, or other medical practitioners, all working together-there is also a duty on each person in the team to communicate diligently with the other medical professionals. The treatment team must take care in comparing notes and make certain that things do not slip through the cracks; elements of treatment or assessment should not be overlooked because each member of the team thinks the other has completed the task. ${ }^{106}$

Courts analyze the responsibilities and actions of various parties involved in a case to reach conclusions on all parties' legal liability based on their degree of blameworthiness. In apportioning responsibility, provincial Negligence Acts ${ }^{107}$ require that courts consider the extent to which each negligent party fell below the required professional standard of care, which "may vary from extremely careless conduct, by which the party shows a reckless indifference or disregard ... down to a momentary or minor lapse of care in conduct which, nevertheless, carries with it the risk of foreseeable harm." ${ }^{108}$ These statutory provisions affirm that

104. Ibid at para 278 .

105. Ibid at para 287.

106. Ibid at para 272.

107. Negligence Act, RSO 1990, c N.1, s 1 (Ontario: "[w]here damages have been caused or contributed to by the fault or neglect of two or more persons, the court shall determine the degree in which each of such persons is at fault or negligent..."); Negligence Act, RSBC 1996, c 333, s 4(1) (British Columbia: "[i]f damage or loss has been caused by the fault of 2 or more persons, the court must determine the degree to which each person was at fault"; Contributory Negligence Act, RSA 2000, c C-27, s 1(1) (Alberta: "[w]hen by fault of 2 or more persons damage or loss is caused to one or more of them, the liability to make good the damage or loss is in proportion to the degree in which each person was at fault..."; Contributory Negligence Act, RSNS 1989, c 95, s 3(1) (Nova Scotia: "[w] here by the fault of two or more persons damage or loss is caused to one or more of them, the liability to make good the damage or loss is in proportion to the degree in which each person was at fault...”). 108. Alberta Wheat Pool v Northwest Pile Driving Ltd, 2000 BCCA 505 at para 46, 233 WAC 113. 
legal responsibility is rooted in a departure from one's own professional duties. The Briante case ultimately failed on the issue of causation, but had it succeeded, the court would have apportioned fault between the nurse and doctor at 80 per cent and 20 per cent, respectively. While the court noted that the doctor was responsible for making a determination about referring a patient for a psychiatric consultation, this patient management responsibility does not mean the doctor is held accountable for deficiencies in the nurse's actions.

Organizational policies may also be relevant in determining the standard of care expected of a health practitioner. For example, a hospital policy may require one practitioner to be designated the "Most Responsible Practitioner" (MRP), a role that carries additional duties for overseeing the totality of a patient's care and goes beyond carrying out the clinical functions within the scope of the MRP's profession and specialty. One case found that an obstetrician was negligent in failing to carry out his MRP role, defined by hospital policy as being "the practitioner most responsible for the in hospital care of a particular patient. The MRP is responsible for writing and clarifying orders, and providing a plan of care, obtaining consultations as appropriate, co-ordinating care, as well as the discharge process." ${ }^{109}$ The trial judge emphasized that, according to this policy, the "MRP was required to participate in a fuller manner by exercising independent critical judgment and ensuring full and complete communication among all treating physicians." 110 In a finding criticized by the dissenting judge on appeal, the obstetrician MRP was found negligent for accepting, without critical scrutiny, a respirologist's treatment plan that was, itself, found to be consistent with the standard of care expected in respirology. ${ }^{111}$ The majority dismissed the appeal, with the following clarification of the MRP role:

We do not understand the trial judge to say that the MRP was required to exercise greater expertise than the respirologists. He stated the case turned on "the determination of the standard of practice for an obstetrician functioning as an MRP". Under the MRP policy, Dr. Halmo was responsible for obtaining consultations as appropriate, for coordinating care, and for a plan of care that addressed the totality of care, not just obstetric issues. ${ }^{112}$

109. Manary v Dr Martin Strban et al, 2011 ONSC 176 at para 37, 198 ACWS (3d) 851 [Manary $v$ Strban Sup Ct].

110. Ibid at para 41.

111. Manary $v$ Strban, 2013 ONCA 319 at para 10, 226 ACWS (3d) 880 Doherty JA [Manary v Strban CA], leave to appeal to SCC refused, [2013] SCCA No 303 (QL), 2013 CanLII 67711 (SCC).

112. Manary $v$ Strban CA, ibid at para 100, Juriansz and Hoy JJA [emphasis in original]. 
It is worth noting that the MRP status was not applied to hold the obstetrician legally liable for the conduct of his colleagues who were working as a team to deliver care to the patient, but rather to expand his own suite of responsibilities. Also key to the outcome in this case was that the obstetrician MRP downplayed his MRP role. This tactic ultimately backfired, as the trial court would not accept that an MRP could offload his or her responsibilities to other members of the care team through an "implied and undocumented understanding." 113

\section{SEQUENTIAL ACTS OF NEGLIGENCE}

Courts have considered team-based care situations in which a health professional was negligent in his or her care of patient and another professional involved in the care of the same patient was subsequently negligent. Questions arise here as to the liability of the first tortfeasor: Does legal responsibility cease or continue when the negligent act of the second tortfeasor occurs? The answer to this question depends on whether the later negligent act breaks a chain of negligence as an unforeseeable novus actus interveniens, or instead, if it compounds the impacts of the prior negligence. The reasonable foreseeability of the later circumstance is the distinguishing factor. ${ }^{114}$ Justice Arnup explains the point:

[Where] there are negligent acts by two persons in succession, I would hold that a person doing a negligent act may, in circumstances lending themselves to that conclusion, be held liable for future damages arising in part from the subsequent negligent act of another, and in part from his own negligence, where such subsequent negligence and consequent damage were reasonably foreseeable as a possible result of his own negligence.

.

The later negligence of [an orthopaedic surgeon] compounded the effects of the earlier negligence of [an emergency physician]. It did not put a halt to the consequences of the first act and attract liability for all damage from that point forward. In my view the trial judge was correct in holding that each of the appellants was liable to the plaintiff and that it was not possible to try to apportion the extent to which each was responsible for the plaintiffs subsequent operation and his permanent disability. ${ }^{115}$

113. Manary v Strban Sup Ct, supra note 109 at para 41; Manary $v$ Strban CA, ibid at para 92.

114. In a Supreme Court of Canada ruling, Justice Dickson clarified: "It is not necessary that one foresee the 'precise concatenation of events'; it is enough to fix liability if one can foresee in a general way the class or character of injury which occurred." Rv Côté et al, [1976] 1 SCR 595 at 604, 3 NR 341.

115. Price v Milawski (1977), 18 OR (2d) 113, 1977 CarswellOnt 644 (WL Can) at paras 51-53 (CA). 
In this case, the emergency physician was negligent in ordering an X-ray of the patient's foot, instead of his ankle, and in failing to diagnose a broken ankle. The orthopaedic surgeon to whom the patient was later referred by his family doctor was negligent in failing to obtain a new X-ray when it was clear the patient had an injury to his ankle, not his foot. The delays in proper diagnosis and treatment caused permanent disability. Both physicians' negligence contributed to this permanent disability.

In contrast, another case involved a rural family doctor whose negligence in treating a newborn masked an underlying congenital disorder and thereby delayed treatment. A paediatrician subsequently involved in the child's care was also negligent in failing to act on unexplained symptoms and failing to arrange a referral to a paediatric endocrinologist. The court determined that the paediatrician's negligence broke the chain of causation, as the family doctor could not reasonably have anticipated the paediatrician's negligence. ${ }^{116}$

116. Phillip (Next Friend of) v Bablitz, 2010 ABQB 566, 192 ACWS (3d) 1012, affd 2011 ABCA 383, 212 ACWS (3d) 263. The trial judge opined that "a reasonable person in the position of [the family doctor] would have brushed aside as far fetched the prospect that a developmental pediatrician faced with considerable evidence that [the infant] Montana's deficits were not accurately explained by the diagnoses in the discharge summary and being responsible for Montana's development nonetheless would fail to refer Montana to a pediatric endocrinologist or clearly recommend to her family physician that such a referral be sought." Ibid at para 334. 


\section{HEALTH CARE ORGANIZATIONS MUST PROVIDE SUPPORTIVE POLICIES AND STRUCTURES}

Health care organizations have a general legal duty to provide safe systems of health service delivery ${ }^{117}$ and to "ensure that proper co-ordination occurs and that the treatment program operates as a unified and cohesive whole." 118 Organizations must provide appropriate supports to help teams function in a coordinated manner. In one case, a hospital adopted a policy concerning information flows and discharge responsibility for patients referred to specialists after admission through the emergency department. ${ }^{119}$ It was well known in the hospital that some specialists did not comply with the policy and, in the case at bar, a patient died after being discharged by specialists who had misdiagnosed his condition. Had the policy been followed, the specialists would have communicated with the emergency department physician who would have ruled out the misdiagnosis and kept the patient for continuing observation. The hospital was found negligent for a "failure to enforce its policies by failing to adopt measures ensuring that the medical staff using its facilities operated as a cohesive whole toward achieving the Hospital's goal of providing better quality health care." ${ }^{20}$ The court concluded that "the Hospital knew or should have known that its failure to implement adequate measures to enforce its ... policy could result in patients being discharged under circumstances which put their health or life in jeopardy."121

In a Manitoba case, Braun Estate $v$ Vaughan, a cytology report was misplaced and, as a result, the patient's cervical cancer was not caught at an early, highly curable stage. ${ }^{122}$ At issue was the lack of a coordinated system to track test results. The court concluded that "[a] doctor is entitled to assume that other members of a professional staff carry out their duties in a competent manner" ${ }^{123}$ but it also found that the doctor had a duty to follow up on test results, which he failed to discharge.

117. See e.g. Yepremian v Scarborough General Hospital (1980), 28 OR (2d) 494, 1980

CarswellOnt 612 (WL Can) at para 139. The court states that "[i]t is also well-established that the hospital is liable to a patient directly for failure to provide what, in other areas of tort liability, would be called a "safe system."

118. Lachambre v Nair et al, [1989] 2 WWR 749, 1989 CanLII 4529 para 137 (Sask QB).

119. Saint John Regional Hospital v Comeau, 2001 NBCA 113, 634 APR 201.

120. Ibid at para 38 .

121. Ibid at para 59.

122. (2000), [2000] 3 WWR 465, 145 Man R (2d) 35 (Man CA).

123. Braun Estate v Vaughan (1998), [1998] 4 WWR 171, 1997 CarswellMan 614 (WL Can) at para 51 (Man QB). 
The Briante case also highlights the need to ensure that organizational policies and procedures that support practitioners in meeting their professional duty of care do not create systems that may, in fact, hinder them from doing so. In Briante, the court expressed concern that the team-based care model emphasized cost-efficient use of health human resources over comprehensive patient assessment. The court hesitated to "fault [the doctor] for doing what was expected of her by the administration of the hospital" but cautioned that the doctor, while working collaboratively with the psychiatric nurse, must fulfill her own professional duties concerning patient evaluation and treatment planning. ${ }^{124}$ Cost savings are one impetus for adopting team models that enable less expensive care providers to perform some tasks traditionally carried out by more highly paid professionals. In medical negligence jurisprudence, however, courts have consistently stressed that patient interests must prevail over health system cost-efficiency goals. ${ }^{125}$ Organizations that implement interprofessional teams must ensure that health care providers have the competencies and resources needed to deliver safe care to patients. Doing so is necessary to promote patients' and professionals' confidence in health care systems.

\section{E. LEGAL LIABILITY AND INTERPROFESSIONAL COLLABORATION}

Courts apply civil liability principles in ways that recognize changing models of health care delivery. They are careful to examine each situation to determine the actions and responsibilities of individual practitioners. The case law reveals that courts interpret standards of care, scopes of practice, and liability in ways that demonstrate an understanding of the goals of team-based interprofessional care and expanded scopes of practice for some professional groups. Lahey and Robert Currie comment that increased judicial findings of negligence in team-based contexts would be a result of "courts misallocating accountability among members of interprofessional teams (sometimes to doctors and sometimes to others), largely due to continuing reliance on traditional understandings of the

124. Briante, supra note 88 at paras 296-97.

125. See Law Estate v Simice (1994), 21 CCLT (2d) 228, 1994 CarswellBC 1117 (WL Can) at para 28 (BCSC). The following statement is a clear example:

... this is a case where, in my opinion, those [funding] constraints worked against the patient's interest by inhibiting the doctors in their judgment of what should be done for him. That is to be deplored. I understand that there are budgetary problems confronting the health care system. ... if it comes to a choice between a physician's responsibility to his or her individual patient and his or her responsibility to the medicare system overall, the former must take precedence in a case such as this. 
allocation of work and responsibility among health care providers." ${ }^{26}$ This does not appear to be happening, however.

The litigation process can help identify problems in meso- and micro-level practices that undermine effective interprofessional collaboration. For example, the importance of good record keeping and communication among team members has been stressed in case law; as an Alberta court observed, "one of the advantages of a shared-care approach for the patient is that two heads examining a problem is better than one. Such is true if the two heads communicate."127 Changes in organizational practices that support team coordination and effective communication will facilitate collaboration and reduce liability risks. In the longer term, widespread adoption of the model of interprofessional collaborative health care practice should improve the quality of care and thereby reduce liability risks.

Another practical matter in regard to liability protection is the need for professionals who work together to ensure they have adequate professional liability cover. Such insurance, which may be a statutory registration requirement for regulated professionals, provides protection for practitioners and patients when situations of negligence arise. ${ }^{128}$ In a joint statement on interprofessional collaboration, the Canadian Medical Protective Association and the Canadian Nurses Protective Society emphasized: "Collaborative practice inevitably reinforces the need for health care professionals to ensure they individually have adequate personal professional liability protection and that the other health care professionals with whom they work collaboratively are also adequately protected so that neither is held financially responsible for the acts or omissions of another."129

126. Supra note 18 at 198.

127. Allen v University Hospitals Board, 2000 ABQB 509 at para 101, 268 AR 261. On the importance of good documentation and communication in team-based care, see also Gemoto, supra note 91 at paras 344-45; Ferguson, supra note 91 at para 148.

128. See e.g. Health Professions Act, supra note 36, s 19(1)(o) (a health professional regulatory college is empowered to require professional liability insurance for registered professionals); Health Professions Act, RSA 2000, c H-7, s 28(1)(c) (individual seeking registration with a professional college must provide evidence of required professional liability insurance); Regulated Health Professions Act, CCSM c R117, s 40(1)(c) (regulated member must provide evidence of any required liability insurance).

129. Canadian Medical Protective Association \& Canadian Nurses Protective Association, CMPA/CNPS Joint Statement on Liability Protection for Nurse Practitioners and Physicians in Collaborative Practice, November 2013 update (Ottawa: Canadian Medical Protective Association \& Canadian Nurses Protective Association, March 2005), online: <www.cnps.ca/ upload-files/pdf_english/CMPA_CNPS_Joint_Statement_Nov_2013.pdf>. 


\section{CONCLUSION: ADVANCING INTERPROFESSIONAL COLLABORATION}

The goals of contemporary reforms to health profession regulation in Canada include promotion of interprofessional collaboration, facilitation of a wider professional scope of practice that includes acts shared with other professions, expansion of scopes of practice for some professions, and recognition of new occupational groups as regulated health professions. Yet, some studies report that the implementation of new roles and models of health service delivery has been a "tortuous journey"130 and a "slow progression." 131 The shift to this regulatory model is incremental, particularly since new legislation is being adopted in a context where statutes have historically regulated professions individually and entrenched models of care delivery have developed within siloed legislative contexts. In British Columbia, for instance, the repeal of profession-specific statutes has taken place over more than a decade as part of the process of moving to an umbrella model of regulation under the province's Health Professions Act. ${ }^{132}$ Other provinces have adopted an approach in which newly recognized health professions are regulated under an umbrella statute and separate statutes remain for existing professions, at least until the governments take another legal step towards consolidating regulation under a unified framework.

Legislative change is a necessary step in creating an enabling macro-level environment, but reform at this level must be accompanied by changes at meso and micro levels that help health professionals work collaboratively within their optimal scope of practice. The ultimate goal is to create environments in which practitioners can "let go of old ways of being and their old identity, and learn new ways of thinking, acting and relating to colleagues, families and patients." 133 In addition to changes to legal frameworks to enable practice roles that support interprofessional collaboration, the provision of education and other supports for health professionals is important so they understand evolving roles and work successfully in new models of care delivery. For instance, in an Ontario survey of approximately three hundred and fifty health care professionals, administrators,

130. Anna-Carin Andregård \& Eva Jangland, "The tortuous journey of introducing the Nurse Practitioner as a new member of the healthcare team: A meta-synthesis" (2015) 29:1 Scand J Caring Sci 3.

131. Verena Schadewaldt et al, supra note 24.

132. See British Columbia Ministry of Health, Legislative Reform, online: <www2.gov.bc.ca/gov/ content/health/practitioner-professional-resources/professional-regulation/legislative-reform>.

133. Teresa Chulach \& Marilou Gagnon, "Working in a 'third space': a closer look at the hybridity, identity and agency of nurse practitioners" (2016) 23:1 Nursing Inquiry 52 at 56. 
and educators, around half of the respondents identified "understanding of the legal, professional, and regulatory guidelines and standards of different providers" as a barrier to interprofessional practice, while approximately 41 per cent said that understanding the scopes of practice of practitioners from other disciplines was a challenge. ${ }^{134}$ Education to dispel misperceptions about liability risks is also important.

Health care organizations and professionals must capitalize on enabling legal environments to realize the promises of interprofessional collaboration. How care providers will work in such models remains to be seen and some analysts identify the risk that "old professional patterns can reemerge," 135 thus stymieing the promise of innovative care models that, in theory, ought to enable practitioners to work to a full scope and improve patient experiences of care and outcomes. The recent Report of the Advisory Panel on Healthcare Innovation describes the Canadian health system as one of "visionary incrementalism."136 Canada was a leader in establishing the Medicare system to provide universal access to health services based on need, but reforms to the system take place slowly. The Panel also criticizes a culture of innovative pilot projects in Canada that are not adopted more broadly. ${ }^{137}$

Organizational policies and procedures and inter-team behaviours are key to supporting successful collaboration and avoiding historic patterns of practice, including effective communication, knowledge of and respect for the work of colleagues from other disciplines, and mutual trust. These factors support well-functioning collaborative teams, which means they also serve to reduce the risk of legal liability. In this way, factors at all levels interact to influence the legal context: supportive meso and micro environments promote effective collaboration, which promotes better experiences of care and outcomes for patients, which, in turn, reduce legal liability risks. The model of collaborative, interprofessional team care itself does not bring liability risks. Rather, it is the way in which the model is deployed in practice that either diminishes or increases risks.

While it is clear that the promotion of interprofessional collaboration is a law reform and health policy priority in many Canadian jurisdictions, it is an

134. Christine Patterson et al, "Interprofessional Resource Centre: a knowledge translation strategy" (2011) 2 Advances in Med Educ \& Prac 35 at 38.

135. Barbara Farrell et al, "Working in interprofessional primary health care teams: What do pharmacists do?” (2013) 9:3 Research in Soc \& Admin Pharmacy 288 at 289.

136. Supra note 14 at 25.

137. The Report observes: "while a number of innovative models for primary care have been rolled out ... [t] here is also little sense of follow-on projects focusing on spreading or scaling-up of these initiatives within a jurisdiction, let alone on a wider geographic basis." Ibid at 27. 
empirical question as to which model of health profession regulation is most supportive of interprofessional collaborative practice. This article has synthesized findings from legislation, case law, and secondary sources to determine how Canadian law supports or enables a shift to interprofessional collaborative practice. Existing qualitative research that examines the experiences of care providers and other stakeholders involved in collaborative practice and affected by new regulatory models has not yet explored legal issues in any detail. ${ }^{138}$ There is clearly much scope for further research to understand the influence of legal factors in practice. ${ }^{139}$ Evaluation of which legal-regulatory models best support interprofessional collaboration in health care indeed demands interdisciplinary collaboration among legal scholars, health care researchers, and social scientists. ${ }^{140}$

138. One recent article reports on interviews with representatives of health professional colleges in Ontario to explore their views on the role of legislation in advancing interprofessional collaboration. Regan et al, supra note 63.

139. Lahey and Fierlbeck, for example, discuss the theoretical strengths and weaknesses of different legislative models and call for research to evaluate their practical outcomes in achieving interprofessional collaboration. Lahey \& Fierlbeck, supra note 43.

140. For discussion of a collaborative research model to investigate "law as a determinant of health system performance", see Scott Burris et al, "Moving from Intersection to Integration: Public Health Law Research and Public Health Systems and Services Research" (2012) 90:2 Milbank Q 375. 